\title{
Kritisk undervisning i KRLE
}

\section{Av Åge J. Schanke og Aina Hammer}

I skolens overordnede styringsdokumenter er kritisk tenkning fremhevet som en sentral ferdighet, og i KRLE-fagets formålsbeskrivelse er det understreket at undervisningen skal voere kritisk. I formålet for faget utdypes det ikke ytterligere hva som legges $i$ kritisk undervisning. Denne artikkelen viser hvordan et utvalg læerere forstår kritisk undervisning i KRLE, og setter søkelys på hvordan læererne begrunner sine forståelser. Det viser seg at lerernes tilnœrming til kritisk undervisning kan sees $i$ sammenheng med deres generelle kritikkforståelse, religionsforståelse og hvordan de forstår danningsoppdraget i faget.

Nøkkelord: KRLE, kritisk undervisning, kritikk, religionskritikk, danning

Age J. Schanke, (f. 1955), universitetslektor ved OsloMet - Storbyuniversitetet,
PB 5, St. Olavs plass, o130 Oslo. E-post: aages@oslomet.no
Aina Hammer, (f. 1973), universitetslektor ved OsloMet - Storbyuniversitetet,
PB 5, St. Olavs plass, o130 Oslo. E-post: ainha@oslomet.no

\section{INTRODUKSJON}

I skolens overordnede styringsdokumenter er kritisk tenkning fremhevet som en sentral ferdighet. I formålsparagrafen heter det blant annet at «Elevane og lærlingane skal lære å tenkje kritisk (...)» (Lovdata, Opplæringsloven §1-1), og i ny overordnet del av læreplanverket understrekes det at «Skolen skal bidra til at elevene blir nysgjerrige og stiller spørsmål, utvikler vitenskapelig og kritisk tenkning og etisk bevissthet.» Det utdypes at kritisk tenkning er en unders $\emptyset$ kende virksomhet hvor fornuften settes i sentrum, og gjennom vitenskapelig tenkning og metode kan etablerte ideer kritiseres og ny innsikt vokse frem. Det fremheves også at kritisk refleksjon forutsetter kunnskap, og at kritisk tenkning kan gjøre elevene i stand til å erkjenne at egne standpunkt og overbevisninger kan være feilaktige. (Udir, 2017). Det kritiske gjenfinnes også eksplisitt i formålsbeskrivelsen til KRLE-faget, hvor det fremheves at undervisningen skal være kritisk (Udir, 2015). Det utdypes likevel ikke hva dette innebærer, og det er derfor rimelig å tenke seg at kritisk undervisning forstås og praktiseres ulikt av lærerne i skolen. Målet for denne artikkelen er nettopp å unders $\varnothing$ ke hvordan et utvalg lærere forstår kritisk undervisning, samt å analysere hvordan de begrunner sine forståelser.

Gjennom intervjuer av seks lærere på seks forskjellige ungdomsskoler i Osloområdet har vi unders $\emptyset \mathrm{kt}$ : Hvordan forstår og begrunner laererne kritisk undervisning i KRLE? 
Vår unders $\emptyset$ kelse forholder seg til kritisk tenkning mer generelt, til kritisk undervisning i KRLE og til religionskritisk undervisning. Det er nødvendig å skille mellom disse kategoriene selv om de nødvendigvis også må sees i sammenheng. Kritisk tenkning og refleksjon tematiseres i skolens grunnlagsdokumenter og forstås der som en grunnleggende og fagovergripende dimensjon, noe alle skolefag skal bidra til å virkeliggjøre. Samtidig konstituerer fagene bestemte kontekster for det kritiske blikket.

Når konteksten er religions- og livssynsundervisning, må nødvendigvis en religionsdidaktisk posisjon få konsekvenser for hvordan kritisk undervisning $\mathrm{i}$ KRLE blir forstått. I analysedelen velges ut tre sentrale aspekter ved en religionsdidaktisk posisjon som utpeker seg som viktige for analysen av lærernes tenkning om kritisk undervisning i KRLE. Kritikkforståelser, religionsforståelser og hvordan de forstår danningsoppdraget i faget, er i spill når lærerne begrunner sitt syn på hva kritisk undervisning bør være.

Kritisk undervisning kan handle om kritisk tilnærming til fagets innhold (religioner, livssyn, etikk) eller til ulike forståelser av dette innholdet (for eksempel slik det representeres i læreb $ø$ kene). Også de betingelsene undervisningsformen gir for elevenes kritiske danning, er med i blikkfeltet.

I det følgende vil vi først tematisere forskningsfelt og metode. Så kommer en resultatdel som viser og systematiserer lærernes forståelse av kritisk undervisning, og dernest en analysedel som drøfter hvordan lærerne begrunner sin forståelse. Teoretiske perspektiver vil introduseres der de anvendes.

\section{TIDLIGERE FORSKNING}

De senere årene har det blitt publisert noe forskning knyttet til kritiske perspektiver og kritisk undervisning i KRLE. I den følgende gjennomgangen vil vi skille mellom normativ og empirisk religionsdidaktisk forskning. Med normativ didaktisk forskning forstår vi bidrag som teoretiserer om hva religionsfaget i skolen bør være, mens empirisk didaktisk forskning i større grad drøfter fagtenkning eller fagpraksiser basert på empirisk materiale. Vår studie er et bidrag inn i den empiriske forskningen, og fordi vi stiller spørsmål som ikke tidligere er stilt et slikt materiale, kan vårt bidrag være med på å nyansere og utvide eksisterende kunnskap.

Når det gjelder empirisk forskning, finnes det ikke mye som går direkte på kritisk undervisning i KRLE, men noen relevante artikler omhandler læreres håndtering av konfliktfylte emner i undervisningen (Anker og von der Lippe, 2015, 2016). Studiene viser at lærere ønsker å unngå kontroversielle emner i undervisningen, og at de ikke føler seg kompetent til, på en didaktisk god måte, å integrere konfliktperspektivet i religionsundervisningen. Det foreligger dessuten noe empirisk forskning som berører kritiske perspektiver knyttet 
til forståelsen av faget (Afset, Kleive \& Hatlebrekke, 2013; Fuglseth, 2017), men disse studienes spørsmål og perspektiver er av en annen art enn det vi utforsker.

Utover disse empiriske studiene finnes særlig to relevante normative studier; Andreassen (2016) har argumentert for å inkludere konflikt- og religionskritiske perspektiver i faget, og mener at dette er relevant for å forstå samfunnet. En religionsundervisning som unngår problematiske trekk ved religion, er ikke troverdig, mener han. Andreassen understreker at en kritisk tilnærming må være basert i en religionsvitenskapelig forståelse. Et annet normativt bidrag kommer fra Schjetne, som har posisjonert seg kritisk til Andreassen. Med utgangspunkt i multikulturalistisk teori setter han elevperspektivet (anerkjennende og identitetsst $\emptyset$ ttende undervisning) opp mot den fagorienterte tenkningen til Andreassen. Schjetne viser en viss tilbakeholdenhet i forhold til religionskritisk undervisning. Han mener at konservative religiøse elever er en kulturelt utsatt gruppe $\ll$ og ugunstig stilte i sammenligning med sekulære og liberale religiøse grupper.» Han foreslår en strategi der lærere kan komme de religiøst konservative elevene i møte, samtidig som de ivaretar sitt ansvar som verdiformidlere (Schjetne, 2014).

\section{Metode}

Høsten 2016 og våren 2017 gjennomførte vi semistrukturerte dybdeintervjuer av seks KRLE-lærere i ungdomsskolen, for å unders $\emptyset$ ke deres forståelse av og begrunnelser for kritisk undervisning i KRLE. Kriteriet for valg av skoler og lærere var at klassene skulle være religiøst og kulturelt mangfoldige. Fem kvinner og én mann sa seg villig til å delta. Intervjuene ble gjennomført på arbeidsplassen eller på en kafé i nærheten av skolen, og alle informantene var etniske norske i alderen $27-45$ år. ${ }^{1}$

Intervjuene varte fra 50 til 90 minutter, ble lydinnspilt og transkribert. Forskningsspørsmålene ble formulert for å unders $\emptyset$ ke lœrernes refleksjoner rundt kritisk undervisning. Derfor har vi ikke gjort elevintervjuer eller klasseromsobservasjon. Det kan hevdes at metoden har sine begrensninger, fordi det kan være avvik mellom hva lærerne sier og hva de faktisk gjør eller mener. Tjora (2017) understreker at forskeren må være oppmerksom på at informantene gjerne vil fremstille seg i et positivt lys, og dessuten fremhever Patton (2002) at logiske brist kan forventes i informantenes svar. Likevel fremhever Laing (1967) at intervjuet som forskningsmetode genererer data, og prosessen kan betraktes som intersubjektiv, i den forstand at intervjueren og informanten kan samhandle og diskutere ulike tolkninger av forskjellige emner. Derfor har vi, slik Cohen, Manion og Morrison (2011) understreker, reflektert over hvilken type inter-

1 Bakgrunnen for kjønnsskjevheten i utvalget er basert på tilfeldigheter, ettersom det var nettopp disse lærerne som sa ja til å delta i undersøkelsen. Prosjektet er meldt til NSD, og informert samtykke er innhentet fra alle lærerne. 
vju som passer best for å samle relevante data, hvilke bias som kan forventes, og dessuten vært klar over egenskapene, styrkene og svakhetene ved det valgte intervju. Ved å benytte en fleksibel og semistrukturert tilnærming, som gjør det mulig å stille oppfølgingsspørsmål og søke avklaringer underveis i intervjuet, har vi fors $\emptyset \mathrm{kt}$ å redusere ulike former for bias og logiske brist. Alle funn er likevel resultat av våre egne og informants fortolkninger (Kvale og Brinkmann, 2009).

Med utgangspunkt i Spradley (1979) og Pattons (1980) kategorisering av ulike typer spørsmål, laget vi en intervjuguide med både beskrivende, reflekterende, erfaringsbaserte og kunnskapsspørsmål. I samsvar med prosedyrer for innholdsanalyse ble alle data kodet (Gibbs, 2007) og kategorisert (Kerlinger, 1970). Vi brukte hyppighet og styrke som verkt $\emptyset$ y for å identifisere forskjeller og likheter. Med hyppighet mener vi temaer som dukket opp ofte i materialet, og med styrke refererer vi til utsagn som virket å være særlig viktige for informantene. Dernest har vi sammenlignet temaer og utsagn for å avdekke mønstre og kategorisere funnene. Unders $\emptyset$ kelsen som helhet har vært eksplorerende og hypotesegenererende. Etter å ha analysert materialet, mener vi å ha funnet en sammenheng mellom lærerens forståelse av kritisk undervisning på den ene siden og deres generelle kritikkforståelse, religionsforståelse og danningsforståelse på den andre.

\section{SEKS LERERE OM KRLE-FAGET}

Våre informanter er blitt gitt fiktive navn, og i det følgende skal vi se hvordan Trond, Gunn, Line, Linda, Trine og Une forstår kritisk undervisning i KRLE. Dernest skal vi drøfte de forhold som ser ut til å ha særlig betydning for deres tenkning om kritisk undervisning.

\section{Hvordan forstår lærerne kritisk undervisning i KRLE? Trond}

Trond fremhever at kritisk undervisning ikke skal være belærende, konfronterende eller negativ, men i stedet legge til rette for meningsutveksling, diskusjon og kildekritikk. Trond understreker at læreren bør «stille gode spørsmål, være flink til å fange opp ting som kanskje ikke er helt slik elevene tror. Det beste jeg kan oppleve når elevene går ut herifra, er at man kan ane at de er blitt litt tankefulle». I møte med det Trond opplever som konservativ religion og «veldig dogmatiske» posisjoner, prøver han å skape refleksjon gjennom å stille spørsmål: «Er alt som står i de hellige skriftene like gyldig, eller skal vi ta hensyn til samfunnet vi lever i?» Men også den religionskritiske gruppen av elever kan innta dogmatiske posisjoner, understreker Trond og utdyper: «Mange elever er anti-religiøse og fullt ut på naturvitenskapelig side. Men boka formidler jo at det finnes et mellomståsted. Jeg vil påstå at det finnes flere. Den ene posisjonen 
trenger ikke å være i konflikt med den andre. Jeg har et behov for å balansere svart-hvit tenkning.»

Vi kan oppsummere Tronds tilnærming til kritisk undervisning i to hovedpunkter:

1 Fremme av kritisk undervisning ved å legge til rette for unders $\emptyset$ kende aktivitet, dialog og meningsutveksling.

2 Fremme av kritisk undervisning gjennom å stille spørsmål som oppmuntrer til kritisk tenkning om konservativ religion, unyanserte fremstillinger og dogmatiske posisjoner.

Her ser vi at Trond forstår kritisk undervisning som en måte å imøtegå polariserte fremstillinger og ytterkantposisjoner på. Han tar avstand fra både dogmatisk sekularisme og konservativ religion, og han har en hermeneutisk tilnærming når han fors $ø$ ker å trene elevene i å se sammenhengene mellom tekst og kontekst. Tronds forståelse av kritisk undervisning kan også sees i sammenheng med at han legger vekt på verdioppdragelse og fremme av liberale verdier. Gjennom å stille spørsmål til rigide posisjoner og konservativ religion, kan han oppøve elevenes kritiske og vitenskapelige tenkemåte, samt fremme elevenes selvrefleksjon.

\section{Gunn}

Før elevene tar stilling til religion og vurderer ulike dimensjoner, må den mest sentrale kunnskapen være på plass, mener Gunn. Hun prioriterer systematisk undervisning fremfor å bruke mye tid på elevytringer med kritisk brodd. Hun vil ikke legge lokk på kritiske utsagn, men går heller ikke inn i dype samtaler om det når det ikke berører et aktuelt kompetansemål. Faget har få timer, og hun rioriterer å rekke over emnene i læreplanen. Gunn legger vekt på å fremstille de ulike tradisjonene på en saklig og lik måte. Eleven skal både kjenne sitt eget og de andres kulturelle grunnlag. Gunn fremhever også at hun sammenligner religioner for å vise at mye er felles.

Gunn understreker at kritikken også må være selvkritisk og innebære vilje til å se på sine egne holdninger og utsagn. Gunn forteller at karikerende beskrivelser av andre grupper forekommer, både hos religiøse og sekulære elever. Hun opplever at elevene på ungdomstrinnet ofte er kritiske, i betydningen skeptiske til religioner, og de kan uttale seg ganske krast som: «Religiøse er idioter» eller «Er du helt dum, eller, som kan tro på det?» Når samtaler mellom religiøse og religionskritiske elever kommer opp i klasserommet, kan det bli høy temperatur. Utsagnene kan bli direkte problematiske, som når en elev sier: «De fortjener å bli drept når de har tegnet Muhammad.» Eller at man «hater alle som kommer fra et annet land som har med seg ikke-vestlig verdier». 
Vi kan oppsummere Gunns forståelse av kritisk undervisning i to hovedpunkter:

1 Kritisk undervisning er aktuelt dersom det er kompetansemål som åpner opp for religionskritiske perspektiver, eller som handler direkte om religionskritikk.

2 Dersom det er tid, er det mulig å åpne for elevytringer med kritisk brodd.

For Gunn handler KRLE-faget om å bygge kunnskap om religioner og livssyn. Kunnskapen skal ligge til grunn før det kritiske bør få en reell plass. Dette er viktig både for at elevene skal forstå sin egen kulturelle arv, og for å dessuten «få en forståelse av folk som tenker annerledes.»

\section{Line}

Line $\emptyset$ nsker å fremme kritiske holdninger gjennom å aktivere elevenes nysgjerrighet: «Det er lov å være nysgjerrig, og synes at ting er annerledes, hvis man viser respekt da. Dessverre reagerer elever ofte negativt på det som er annerledes. Så fort det er noe fremmed er det liksom; 'Ha-ha, de er teite eller de der er dumme'. Så jeg har brukt ganske mye tid på å luke vekk de holdningene der.» Line mener det skal være rom for religionskritiske spørsmål fra elever i KRLE. Hun forteller at mange elever er opptatt av IS og kommer med utsagn som «De er jo helt gærne de derre muslimene.» Da blir det nødvendig «å fortelle de litt om hvor den gruppa har kommet fra, og forklare at en religion ikke bare er sånn eller slik.» Det er likevel ikke ofte elever kommer med religionskritiske innspill i timene, selv om det er rom for det. Line er opptatt av at det skal stilles krav til hvordan elevene uttrykker kritikk: «Man bør formulere seg litt med takt og tone, og man trenger ikke si «så teit det ser ut», men man kan jo stille spørsmålet; «hvorfor går de med sånne klær?». Selv påpeker Line negative sider særlig ved konservativ kristendom. Hun er kritisk til en ill-liberal kristen praksis «der troen du handler på, går utover andre mennesker, enten det gjelder diskriminering eller utestengning». «Religionskritikk kan være ganske ulike ting. Den kan også inngå i det å finne sin egen vei gjennom refleksjon over ulike muligheter». Line fremhever at fagets sentrale hensikt er å «forstå hverandre på et vis, da, og få en forklaring på hvorfor noen velger å leve slik eller sånn».

Vi kan oppsummere Lines forståelse av kritisk undervisning i tre hovedpunkter:

1 Kritikk bør rettes mot tro eller livssyn som diskriminerer eller utestenger mennesker.

2 Kritisk undervisning skal stimulere elever til å luke vekk fordommer og skape respekt og forståelse.

3 Kritisk undervisning kan handle om å stimulere elevene til å ha en selvstendig og undersøkende tilnærming til religioner og livssyn. 
Line mener at fagets hovedformål er å fremme forståelse, etisk tenkning, moralsk handling, og refleksjon. Hun begrunner sin tilnærming til kritisk undervisning i disse komponentene.

\section{Linda}

Linda er reservert overfor noen forståelser av hva kritisk undervisning kan være, og hun mener det ikke er dekning i læreplanen for et gjennomgående religionskritisk fokus i undervisning. Linda fremhever likevel at elevenes ulike syn skal få komme til uttrykk, og dessuten skal læreren undervise i kompetansemål med kritiske perspektiver, som for eksempel drøfte ulike syn på Bibelen. Hun understreker at det kritiske også finnes implisitt i undervisning om mangfold og $i$ et mangfoldig klasserom, fordi elevene blir presentert for ulike syn som alle gjør krav på sannhet. Hun utdyper: «Det er et stort mangfold i klassene på vår skole, så for meg er det viktig at dette faget kan hjelpe til med at vi kan prate sammen og forstå hverandre, i den verden vi lever i. Da lærer man respekt, og elevene er ofte vennegjenger også på tvers av tro og livssyn, og da blir det ikke den hatkritikken». Linda sier at elevene sjelden kommer med religionskritiske innspill i en faglig setting. Den negativt ladete kritikken kan komme mer som en slengbemerkning $i$ et friminutt.

Linda mener at når religionskritikken blir hånlig og latterliggjørende rammer den religiøse mennesker på en negativ måte. Hun forklarer: «Det kan skje i forhold til muslimer i dag. På 60-70-80 tallet ble kristne av og til rammet av en type latterliggjørende og karikerte fremstillinger.» Linda mener at konservativ religion ofte er problematisk, og at det kritiske da er på sin plass. Hun fremhever $i$ tillegg at det er viktig at mennesker selv finner ut hva som er problematisk og blir i stand til å revidere sine posisjoner. Hun understreker også at kritisk undervisning som rokker ved elevenes livssyn og skaper konflikt, er problematisk. «Det er ikke skolens oppgave å skulle endre menneskers livsholdning, den skal gi informasjon.»

Vi kan oppsummere Lindas forståelse av kritisk undervisning i fire hovedpunkter:

1 Kritisk undervisning skal finne sted når kompetansemålene legger opp til det.

2 Kritisk undervisning finnes implisitt $\mathrm{i}$ alle mangfoldige klasserom og $\mathrm{i}$ pluralistisk undervisning.

3 Kritisk undervisning handler om å trene elevene i å oppdage problematiske sider ved religion, og da særlig knyttet til konservativ religion.

4 Kritisk undervisning handler om å forstå egne og andres perspektiver og trosoppfatninger. 
Linda begrunner sin tilnærming til kritisk undervisning ved å vise til at faget skal skape forståelse, samhold, og respekt. Faget skal være en arena for å kunne snakke om ulikhet. Det kritiske i faget ligger innebakt i det faktum at skolefaget er pluralistisk.

\section{Trine}

Trine understreker at kritisk tilnærming handler om å stille spørsmål til både sin egen og andres religion. Trine mener at solid kunnskap gjennom god religionsundervisning, sammen med kritisk tenkning, kan forhindre fordommer, fremmedfrykt og hat. En lærer bør derfor «ha nok kunnskap i faget til å kunne korrigere elevenes inntrykk av religionene slik de fremstilles i media». Trine mener at religioner brukes til å gjøre ekstremt mye vondt i verden, men understreker: «det er ikke nødvendigvis religion i og for seg som er problemet, men folks tolkning og bruk av religion.» Trine mener at religionskritikk er særlig relevant for islam, «siden muslimer bruker religion som en unnskyldning for krigføring.» Elever skal trenes i å se «sammenhenger mellom religion, etikk og demokrati, styresett og ytringsfrihet.» Trine forklarer at elever av og til kommer med utsagn som synes å være i konflikt med skolens verdier: «Utspill som at det er greit å drepe hvis man karikerer Muhammed er ikke greie. Sånne utspill kan ikke komme fra en fredelig religion».

Trine forteller om intense diskusjoner i klassen, særlig i forbindelse med det muslimske elever oppfattet som krenkelse. Hun forklarer: «Man må jo også åpne for litt dagsaktuelle ting i KRLE, det er jo viktig, og da kan det bli heftig diskusjon.» Trine understreker at hun opplever det som særdeles krevende å stå i situasjoner hvor elevene ytrer at du fortjener å dø hvis du tegner Muhammed, og at hun arbeider med å trene i elevene i å begrunne sine standpunkter. Trine sier også at hun er redd for at noen kan føle seg støtt, dersom det er et tema hun ikke klarer å pakke inn på en hyggelig måte, eller hun ikke kan gi tilstrekkelig informasjon om et tema. Dette er spesielt framtredende i forhold til islam. Trine understreker at hun reflekterer over dette i undervisningsforberedelsen, og det kan få konsekvenser for hvordan hun legger opp undervisningen.

Vi kan oppsummere Trines forståelse av kritisk undervisning i fire hovedpunkter:

1 Kritisk undervisning skal trene elevene i å se både sine egne og andres oppfatninger i et kritisk lys.

2 Kritisk undervisning kan være et middel til å dekonstruere fordommer, fremmedfrykt og hat.

3 Kritisk undervisning handler om å trene elevene i å begrunne sine standpunkter.

4 Kritisk undervisning bygger opp under skolens verdigrunnlag. 
Vi kan se at Trine mener KRLE-fagets overordnede mål handler om å fremme en kritisk og kunnskapsbasert tilnœerming til religioner og livssyn, hvor arbeidet med elevenes fordommer og holdninger står sentralt.

\section{Une}

Une mener at sammenlikning er en måte å oppøve et kritisk blikk på. Hun fremhever at når elever sammenligner og reflekterer over likheter og forskjeller, ligger det en mulighet for kritikk; både kritikk rettet mot andres posisjoner, men også refleksiv bevissthet $i$ forhold til sin egen posisjon. Une understreker at i en samtale med religionskritiske elementer må deltakerne være saklige og respektfulle, og det må ligge en gjensidig anerkjennelse av at den andre har noe viktig å si. Man må lytte og prøve å forstå den andres ståsted. Selvsensur kan være en faktor som begrenser den åpne samtalen. Une tenker at skolen har en del normative føringer på hva som er greit å si og ikke si i klasserommet. «Når skolens normative føringer blir sterke, kan det føre til at noen ytringer dyttes ut av klasserommet, ting som det virkelig hadde vært bra å snakke om. Men det skal jo også være noen grenser. Vi skal ikke ha krenkelser i KRLE-klassen.»

Une mener at saklig og argumentativ religionskritikk er viktig når den er rettet mot maktstrukturer, religionens negative funksjon i samfunnet eller mot dens etiske grunnlag. Derimot er Une reservert i forhold til religionskritikk som går på tro eller praksiser som ikke har negative moralske implikasjoner, og spesielt når den tar from av latterliggjøring og krenkelser. Hun mener at det å kritisere treenigheten eller troen på én gud er lite fruktbart.

Vi kan oppsummere Unes forståelse av kritisk undervisning i tre hovedpunkter:

1 Kritisk undervisning og refleksivitet kan fremmes gjennom sammenligning av ulike posisjoner.

2 Kritisk undervisning kan fremmes gjennom strukturert samtale og dialogferdigheter.

3 Kritisk undervisning og religionskritikk bør rettes mot problematiske maktstrukturer og det etiske grunnlaget i religionene.

Une mener at KRLE-faget bør forstås både som et kunnskaps-, refleksjons- og dialogfag. Une prioriterer å skape et godt klima for åpne samtaler om religion og livssyn.

\section{HVORDAN BEGRUNNER LÆRERNE SIN FORSTÅELSE AV KRITISK UNDERVISNING I KRLE?}

Vi har nå presentert og systematisert hvordan de seks lærerne forstår kritisk undervisning i KRLE. Målet har vært å fă fram sentrale sider ved deres for- 
ståelse. Vi har sett at de delvis vektlegger ulike aspekter eller sider ved kritisk undervisning, samtidig som vi også finner sammenfallende forståelser. I den følgende analysen har vi undersøkt hvordan de begrunner sine forståelser, og særlig relevant for å få fram likheter og forskjeller i lærernes begrunnelser, er å se dem i sammenheng med kritikkforståelse, religionsforståelse og forståelse av danningsoppdraget i KRLE.

\section{Lærernes kritikkforståelse og implikasjoner for kritisk undervisning}

Etymologisk betyr begrepet kritisk å 'dømme', 'avgjøre' eller 'skjelne' (SNL, 2017). Med kritisk tenkning menes som oftest en åpen vurderingsprosess, der utfallet ikke er gitt på forhånd. Kritisk kan da innebære at tenkning eller refleksjon ikke bare beskriver noe, men også vurderer for eksempel sannhet, verdi eller kvalitet. Selvstendighet, uavhengighet, nøyaktighet er egenskaper som forbindes med å tenke og forholde seg kritisk. Enhver vurdering bygger på implisitte eller eksplisitte kriterier som normer, verdier, idealer eller oppfatninger.

Med kritikkforståelse mener vi en overordnet og generell oppfatning av hva kritisk innebærer. En kritikkforståelse vil selvfølgelig være sentral i tenkningen om hva kritisk undervisning i KRLE innebærer, og vil være bakenforliggende i slike refleksjoner. Et fors $\emptyset \mathrm{k}$ på systematisering av kritikkforståelser finner vi hos Kalm og Bexell (2017). De har gjort en empirisk studie av kritisk tenkning i forskerutdanning i Sverige, og fant fire hovedoppfatninger:

1 Kritikk som skepsis og granskning innebærer å være kritisk til argumentasjon og å kreve logisk konsistens eller belegg for det som hevdes.

2 Kritikk som kreativitet og selvstendighet impliserer å kunne reflektere på egen hånd, løse problemer, ha overblikk og være selvstendig ved å komme med egne bidrag.

3 Kritikk som avdekking av maktstrukturer handler om å stille spørsmål ved dominerende diskurser og det som vanligvis ikke problematiseres, og videre undersøke hvilke maktforhold som er i spill. Dette berører også det å anerkjenne at egen posisjon ikke er nøytral.

4 Refleksiv selvkritikk handler om å kritisk vurdere egne oppfatninger og stille spørsmål ved det man selv tar for gitt.

I vårt materiale kan vi gjenfinne alle kategoriene til Kalm og Bexell (2017). En hovedtendens blant lærerne er likevel at de oppfatter kritikk som det Kalm og Bexell kaller for kritikk som kreativitet og selvstendighet. Lærerne mener at kritisk handler om å undersøke noe grundig, stille spørsmål, utvikle selvstendige meninger og nyanserte beskrivelser. Vi finner også at alle lærerne ønsker å fremme elevenes refleksive selvkritikk. Elevene skal trenes i å stille spørsmål og 
kritisk vurdere sine egne oppfatninger. I materialet finner vi også spor av andre kritikkforståelser som skepsis og granskning og kritikk som avdekking av maktstrukturer (Kalm og Bexell 2017). Dette er kanskje aller mest uttalt hos Trine og Une. Det er dessuten mulig å tenke seg at denne formen for kritisk tenkning også er til stede når elevene kritiserer hverandres posisjoner, som når lærerne beskriver at det oppstår harde fronter og opphetede debatter i klassene.

\section{Lærernes religionsforståelse og implikasjoner for kritisk undervisning}

Religion kan forstås og vurderes på en skala fra entydig positiv til entydig negativ. ${ }^{2}$ For å få fram ulike nyanser, foreslår vi her en skala på fem posisjoner:

1 En positiv empatisk religionsforståelse, der religionskritikk ikke har noen plass. Religion oppleves som et gode «i seg selv.» En slik positiv forståelse vil ofte være begrenset til egen tro. Også religionsfenomenologiske tilnærminger finnes i denne kategorien.

2 Religion er i hovedsak positivt, men det betinger at den aktuelle religionen forvaltes og kultiveres i samsvar med allmennetiske idealer. Derfor er en partiell og konkret religionskritikk rettet mot bestemte forestillinger, praksiser og verdier både legitim og nødvendig.

3 Et semisekulært syn kan kategoriseres som hverken religiøst eller sekulært. Det handler om en vag, ambivalent vurdering av religion, som ikke er tydelig positiv eller negativ. Denne posisjonen er vanlig hos postkristne skandinaver som ikke aktivt deltar i religiøse organisasjoner. Folk i denne kategorien er hverken spesielt engasjert $\mathrm{i}$ - eller spesielt kritisk til - religion.

4 I hovedsak et negativt syn på religion, men i denne posisjonen finnes likevel en åpenhet for at det eksisterer verdier i religion som kan oversettes og integreres i en sekulær kultursammenheng.

5 Et negativt «sekularistisk» eller positivistisk syn på religion. Religion er et onde «i seg selv» og et prinsipielt tilbakelagt fenomen.

Vi kan si at posisjon 1 og 5 legger til grunn en essensialistisk religionsforståelse, mens posisjonene 2, 3 og $4 \mathrm{i}$ mer eller mindre grad forstår religion som kulturelt og historisk betinget. Fem av seks lærere i vårt materiale har en relativt positiv grunnholdning til åpen og liberal religion og religiøsitet. De uttrykker likevel en klar demarkasjonsgrense mot autoritær, dogmatisk og konservativ religion og religiøsitet. Trond, Gunn, Line, Linda og Une kan plaserers i kategoriene 2-4. Trond, Linda og Line ser ut til å falle mest i kategori 3, mens Gunn nok heller mot posisjon 2. Trine skiller seg ut med et hardere kritisk syn på religion, og kan muligens plasseres i posisjon 5 .

2 I dette forsøket på å skissere en typologi over posisjoner, trekker vi veksler på teoretiske perspektiver fra en rekke forskere: Andreassen (2016), Flensner (2015), af Burén (2015) 
Vi har sett at lærerne i vårt materiale har en religionsforståelse som åpner for konkret og spesifikk religionskritikk i klassen. Lærerne stiller seg likevel ikke bak den klassiske religionskritikken rettet mot religion som fenomen, men åpner for moralsk kritikk begrunnet $\mathrm{i}$ liberale verdier og skolens overordnede styringsdokumenter. Denne kritikken er ofte rettet mot hva de forstår som illegitime praksiser og maktmisbruk. Ingen av våre informanter har en ensidig positiv religionsforståelse, og undervisningen inkluderer det Anderssen (2016) kaller for konfliktperspektiver.

\section{Lærernes forståelse av danningsoppdraget i KRLE og implikasjoner for kritisk undervisning}

I læreplanen antydes en rekke formål med faget gjennom stikkord som felles kunnskapsgrunnlag og referanserammer, livstolkning, etisk bevissthet, forståelse på tvers av tros- og livssynsgrenser, forstå kulturer, kulturarv, dialog og respekt for religiøse verdier, menneskerettighetene og menneskerettighetenes etiske grunnlag (Udir, 2015). Når lærerne fortolker disse sidene ved fagets formål, synliggjøres også deres danningsperspektiv. Dette har videre implikasjoner for lærernes forståelse av kritisk undervisning.

Danning er et svært sentralt begrep i pedagogikk og fagdidaktikk som har fătt betydelig oppmerksomhet i den senere tid. Samtidig er det et noe komplekst og til dels vagt begrep med en lang begrepshistorie. Med Paul Martin Opdal (2010) oppfatter vi danning som et pedagogisk fundamentalbegrep. Begrepet «impliserer både en utvikling henimot en stadig økende grad av kunnskap, innsikt og forståelse», men også «en endring til det bedre» og at danning medfører en «transformasjon av de måter personen tenker, handler og føler på.» Danning krever dialog i betydningen forpliktende og sannhetss $ø$ kende debatter mellom likeverdige personer, og dannelse virker frigjørende og bidrar dermed til utvikling av det autonome mennesket.

Bernt Gustavsson (2003) knytter danning til tre dimensjoner, nemlig samfunns-, kunnskaps--, og individdimensjon. Geir Skeie (2014) bygger videre på disse dimensjonene, og vi har funnet dem hensiktsmessige for å analysere lærerens tilnærming til kritisk undervisning. Samfunnsdimensjonen handler om hva eleven trenger for å bli god samfunnsdeltaker: verdiperspektiver, menneskerettigheter, dialogferdigheter, kulturarv og sosialisering til moderne verdier. Kunnskapsdimensjonen handler om å ha kunnskap om religioner og livssyn og dessuten å gjenkjenne om denne kunnskapen er basert i et innenfra- eller utenfraperspektiv. Den individuelle dimensjonen vil dreie seg om selvutvikling, meningsdanning, livstolkning, identitetsdanning.

Robert Jackson (1997) har vektlagt et individorientert danningsperspektiv i sin fortolkende tilnærming til religionsundervisning. Elever skal ikke bare $\emptyset \mathrm{ke}$ 
sin kunnskap om religion, men også reflektere over konsekvenser kunnskapen kan ha for deres egen forståelse og verdier (refleksivitet). En slik refleksjon kan føre til edification, dvs. til revurdering av egen livsforståelse og verdier. Slike kritiske vurderinger handler om å om å bli mer bevisst sitt eget ståsted, synspunkter og fordommer, for så å utforske og utfordre disse.

Under følger en systematisering av lærenes danningsperspektiver. Vi finner at samfunnsdimensjonen står sentralt, gjennom blant annet danning til medborgerskap, dialogferdigheter og verdisosialisering, men også kunnskaps- og individdimensjonen blir trukket fram. Vi mener å se at alle de tre dimensjonene er til stede hos alle lærerne, men de har ulik betoning og vektlegging av disse. Derfor vil vi under trekke frem de perspektivene på danning som tydeligst ser ut til å forme de ulike lærernes tilnærming til kritisk undervisning.

\section{Samfunnsdimensjonen}

For Trond er verdiperspektivet sentralt i hans danningsforståelse. Han fremhever at skolefaget skal bidra til verdioppdragelse og fremme av liberale verdier som toleranse og respekt. Dermed blir det en tydelig kritisk brodd mot konservativ religion og dogmatiske posisjoner. Gunn legger vekt på kulturarvperspektivet og understreker at elevene skal kjenne både sitt eget og andres kulturelle grunnlag. Hun sammenligner religioner for å vise at mye er felles, og det kritiske tones derfor i stor grad ned. Trines danningstenkning kretser om verdiperspektiver og en slags demokratisk medborgerskapstenkning, idet hun mener elevene bør kunne se «sammenhenger mellom religion, etikk og demokrati, styresett og ytringsfrihet». Hun peker på elevenes holdningsdanning som sentral i faget, og har en tydelig kritisk tilnærming til religion og religiøse posisjoner som går imot moderne menneskerettstenkning. Unes danningsperspektiv ligger særlig $i$ hennes forståelse av dialog som danning. Hun ser KRLE som et refleksjons- og dialogfag der ferdigheter $\mathrm{i}$ å håndtere uenighet har en sentral plass. Une er den eneste av lærerne som uttrykker en viss bekymring for at skolens verdigrunnlag implisitt kan kneble kritiske ytringer som går på tvers av skolens verdier. Une mener at $i$ en sammenlignende tilnærming $i$ undervisningen ligger mulighet for kritikk rettet mot andres posisjoner, men også mulighet for å fremme en refleksiv bevissthet i forhold til sin egen posisjon. Linda har et tydelig mangfoldsperspektiv på den samfunnsmessige danningen, og er særlig opptatt av hvordan KRLE kan bidra til å fremme samhold, forståelse og respekt på tvers av ulikhet. Hun mener at det kritiske finnes implisitt i fagets pluralistiske karakter, fordi ulike sannhetskrav kan relativisere eget syn og fremme både refleksiv selvkritikk og kritikk rettet mot andres posisjoner. 
Gunn har både et kunnskapsorientert og et samfunnsorientert perspektiv på danning i KRLE. Hun mener at kunnskap skal utgjøre et solid fundament hos elevene, og at dette må ligge til grunn før de er modne for kritisk undervisning og religionskritikk. Lines danningsperspektiv kretser også omkring kunnskap. Hun mener kunnskap om religion og ulike religiøse grupper vil bidra til en utvidet forståelse av eget og andres perspektiver. Hun har dessuten fokus på etikk i religionene, og vil rette et kritisk blikk mot tenkning og praksiser som diskriminerer og utestenger. Hun vektlegger også kunnskapens sosiale betydning, fordi kunnskap kan bidra til forståelsen av hverandre. Trines danningsperspektiv handler om å gi elevene et solid kunnskapsgrunnlag som også fokuserer på konfliktperspektiver og problematiske trekk ved religionene. Gjennom slik kunnskap kan elevene se egne og andres oppfatninger i et kritisk lys, og dette kan igjen bidra til å dekonstruere fordommer og hat. Une forstår faget både som kunnskapsfag, refleksjons- og dialogfag. Hun vil holde sammen alle de tre dimensjonene. Det er viktig at læreren sørger for at kunnskap om fagets områder blir bygd, men det er like viktig at læreren legger til rette for refleksjon og dialog. Gjennom strukturert dialog kan elevenes kritiske ferdigheter trenes gjennom å ta stilling, lytte aktivt og vurdere ulike påstander og oppfatninger.

\section{Individdimensjonen}

Danningsperspektiver knyttet til selvutvikling og meningsdanning kommenteres i liten grad i vårt materiale. Individdimensjonen, slik Skeie beskriver den, er lite eksplisitt til stede hos de fleste lærerne. Men Une representerer danningsperspektivet vi finner i Jackson's reflexivity. Une understreker at identitet og livstolkning er noe lærerne ikke må prøve å styre, kun skape et rom for. I mer generell forstand finner vi også hos alle lærerne et fokus på å trene elevenes refleksivitet, i betydningen å se egen forståelse og verdier i nytt lys.

\section{OPPSUMMERING OG KONKLUSJON}

Vi har unders $\emptyset$ kt hvordan seks lærere forstår og begrunner kritisk undervisning i KRLE.

I vårt materiale finner vi bred enighet om at kritisk undervisning kan forstås som beskrivende undervisning om religionskritikk eller undervisning knyttet til kompetansemål som åpner for religionskritiske perspektiver. Lærerne stiller seg også bak kritisk undervisning som legger til rette for undersøkende aktivitet, dialog, meningsutveksling. Det kritiske kan også handle om å forstå egne og andres perspektiver og trosoppfatninger, og å utvikle refleksivitet. Lærerne mener det skal være rom for kritiske elevytringer, og de fremhever at det kritiske finnes implisitt i pluralistisk undervisning i mangfoldige klasserom. Det er 
religion som i hovedsak er gjenstand for kritiske vurderinger. Andre emneområder som livssyn, etikk og filosofi blir i liten grad tematisert av lærerne.

Men vi fant også nyanser mellom lærerne i forståelsen av hva kritisk undervisning bør eller ikke bør innebære, og i hvordan den religionskritiske dimensjonen ble vektlagt. Linda oppfatter det religionskritiske som begrenset til de aktuelle kompetansemålene, og til elevytringer med religionskritikk. Et religionskritisk fokus i undervisning skal ikke være gjennomgående, og konfronterende kritikk av religiøse posisjoner bør unngås. Andre lærere, som Gunn og Trond, synes å mene at kritisk undervisning dels $b \emptyset r$ rettes mot negative sider ved religion, og dels mot elevenes egne fortolkninger av religion. Une vil skille mellom kritikk av tro og kritikk av etikk, og argumenterer for at velbegrunnet moralsk kritikk av religion er legitimt i klasserommet, men kritikk av tro bør unngås. Kritikk av tro blir ofte latterliggjørende og problematisk. Trine anser derimot religionskritikk som generelt legitim i klasserommet under forutsetning av at den er kunnskapsbasert. Kritisk undervisning i KRLE handler imidlertid ikke bare om religionskritisk undervisning. Det kritiske blikket må også rettes mot vrengebilder og mistolkninger av religion. Dette anliggende kommer særlig fram hos Line. Kritisk undervisning luker bort fordommer og problematiserer forvrengte oppfatninger av religion, og skaper slik respekt og forståelse. Unes tilnærming til kritisk undervisning handler i stor grad om sammenlignende metarefleksjon over eget og andres livssyn. En slik refleksjon kan føre til videreutvikling eller ny vurdering av egen posisjon. Denne formen for kritikk gjør ikke krav på å være allmenngyldig, men er basert i personlige vurderinger. Kritisk undervisning kan også være verdiorientert og oppdragende, og slik problematisere verdier i konservativ religion. Trond representerer denne forståelsen av kritisk undervisning.

Ulike forståelser av kritikk, religion og danning er i spill når lærerne begrunner sitt syn på hva kritisk undervisning i skolefaget bør være. Lærerne har i stor grad sammenfallende kritikkforståelse, og vi har sett at selvrefleksjon, selvstendighet og det å kunne vurdere og stille spørsmål ved egne oppfatninger blir ansett som vesentlige elementer. Dette er i samsvar med hvordan overordnet del av læreplanverket beskriver kritisk tenkning. Her fremheves nettopp at undervisningen skal oppøve elevenes evne til å erkjenne at egne standpunkt og overbevisninger kan være feilaktige.

Når det gjelder religionsforståelse, samlet de fleste lærere seg om midtposisjoner, og ga uttrykk for en relativt positiv grunnholdning til åpen og liberal religion og religiøsitet, men posisjonerte seg kritisk til autoritær og dogmatisk religion. Det førte til en viss åpenhet for religionskritikk og konfliktperspektiver på religion, slik Andreassen tar til orde for, men lærerne stilte seg i hovedsak kun bak spesifikk religionskritikk rettet mot trosforestillinger eller praksiser som forstås som etisk og moralsk problematiske. En av lærerne representerer et 
mer sekularistisk og kritisk syn på religion.

For lærere kan utfordrende tema og konfliktorienterte perspektiver være en krevende $\emptyset$ velse i et mangfoldig klasserom. Noen av lærerne uttrykte reservasjon mot å tematisere religionskritikk som kunne ramme elever. Selv om ikke lærerne snakket eksplisitt om å ivareta konservative elever, slik Schjetne tar til orde for, henger reservasjonen muligens sammen med en elevorientering, der hensynet til elevens identitet og tilhørighet spiller en stor rolle. Dette perspektivet er en sentral side ved tenkningen til Schjetne (2014). Det kan også tenkes at usikkerhet knyttet til egen kompetanse kan bidra til at lærere har forbehold mot å bringe inn kontroversielle tema i undervisningen, slik Anker og von der Lippe $(2015,2016)$ påpeker, og derfor heller omgår vanskelig tematikk. Opplevelsen av å være kompetent eller ikke, ble ikke tematisert i intervjuene, slik at vårt materiale gir ikke holdepunkter for en konklusjon her.

Danningsforståelsen tematiserer spørsmål som: Hva er viktigst i undervisningen, å gi eleven kunnskap om religion og livssyn, å legge til rette for livstolkning og identitetsdanning, eller gi eleven forutsetninger for å bli en god samfunnsborger? Disse valgene får betydelige konsekvenser for hvordan kritisk undervisning forstås, og vi har sett at lærerne vektlegger ulike dimensjoner ved danning. Lærerne i vårt materiale fokuserte mest på samfunnsdimensjonen ved danningsoppdraget i faget. Også kunnskapsdimensjonen er viktig for de fleste, mens individdimensjonen får mindre oppmerksomhet av lærerne med ett unntak.

Når samfunnsdanning er en vektlagt dimensjon, kommer verdisosialisering i fokus, og dermed også en potensiell kritikk av konservativ religion med tradisjonell verdiorientering. Når kunnskapsdimensjonen vektlegges, er det gjerne andre sider ved religion som det kritiske blikket rettes mot, som for eksempel religioners selvforståelse og historiefortellinger. En individrettet danningsforståelse vektlegger mulighetene for personlig forståelse og tolkning.

Selv om vårt materiale ikke er generaliserbart, har vi synliggjort at tenkning og praksis blant lærerne har en betydelig spennvidde, og våre hovedfunn viser at tilnærming til kritisk undervisning kan sees i sammenheng med hvordan lærerne posisjonerer seg i forhold til kritisk tenkning, religionsforståelse og danningsforståelse. 


\section{LITTERATUR}

af Burén, A. (2015). Living Simultaneity. On religion among semi-secular Swedes.

Andreassen, B.-O. (2016). Religionsdidaktikk. En innføring (2. utg. ed.). Oslo: Universitetsforl.

Afset, B., Kleive, H. V., \& Hatlebrekke, K. (2013). Kunnskap til hva? Om religion i skolen (Vol. nr. 20). Trondheim: Akademika forlag.

Anker, T. \& Lippe, von der, M. (2015). «Når terror ties i hjel En diskusjon om 22. juli og demokratisk medborgerskap i skolen.» Norsk pedagogisk tidsskrift, 99(2), s. $85-96$.

Anker, T., \& Lippe, M. v. d. (2016). «Tid for terror. Læreres håndtering av kontroversielle spørsmål i skolens religions- og livssynsundervisning.» Prismet, o(4), 261. doi:10.5617/pri.4478

Cohen, L., Manion, L., \& Morrison, K. (red.) (2011). Research methods in education. London og New York: Routledge.

Flensner, K. K. (2015). Religious Education in Contemporary Pluralistic Sweden.

Fuglseth, K. S. (2017). «Orienteringas bakside: 'Indirekte undervisning' og mangelen på engasjement, interesse og motivasjon.» Prismet, o(2), 79. doi:10.5617/pri.4501

Gibbs, G. (2007). Analyzing qualitative data. London, UK: Heinemann.

Gustavsson, B. (2003). Bildning i vår tid. Om bildningens möjligheter och villkor $i$ det moderna samhället. Stockholm: Wahlstrøm \& Widstrand.

Jackson, R. (1997). Religious education. An interpretive approach. London: Hodder \& Stoughton.

Kalm, S., \& Bexell, M. (2017). «Kritiskt tänkande i forskarutbildningen handledares röster om ett betydelsefullt examensmål.» Högre Utbildning, 7(2), 1-17. doi:10.23865/hu.v7.1026

Kerlinger, F. N. (1970). Foundations of behavioral research. New York, NY: Holt, Reinhart \& Winston.

Kvale, S. \& Brinkmann, S. (2009). Det kvalitative forskningsintervju. Oslo: Gyldendal akademisk.

Laing,R.D.(1967). The Politics of Experience and the Bird of Paradise. Harmondsworth: Penguin

Lovdata. (2017). Opplæringsloven §1-1. Hentet 06.03.18 fra: https://lovdata.no/dokument/NL/lov/1998-07-17-61

Opdal, P. M. (2010). «Dannelsesbegrepet som fundamentalbegrep.» I M. Brekke (red.), Dannelse i skole og larerutdanning (pp. s. 18-28). Oslo: Universitetsforl., 2010

Patton, M. Q. (2002). Qualitative research \& evaluation methods (3.utg. red.). Thousand Oaks, Calif: Sage Publications.

Schjetne, E. (2014). «Kritisk blikk på kritikk. Religionskritikk som balansekunst i den offentlige skolen.» I (Vol. Kap. 9, pp. 153-176). [Oslo]: Cappelen Damm akademisk, 2014. 
Skeie, G. (2014). «RLE som dannelsesfag.» Religion og livssyn, 26(3), 12-17.

SNL (2017). Kritisk. Hentet 02.03.18 fra: https://snl.no/kritisk

Spradley, J. P. (1979). The ethnographic interview. New York: Holt, Rinehart \& Winston. Tjora, A. H. (2017). Kvalitative forskningsmetoder i praksis (3. utg.) Oslo: Gyldendal akademisk.

Udir. (2015). Lareplan i kristendom, religion, livssyn og etikk (KRLE). Hentet 23.01.18 fra: https://www.udir.no/klo6/RLE1-02

Udir. (2017). Overordnet del av læreplanverket. Hentet 04.04.18 frå: https://www. regjeringen.no/contentassets/37f2f7e1850046aoa3f676fd45851384/overordnetdel---verdier-og-prinsipper-for-grunnopplaringen.pdf 